\title{
NOTA/NOTE
}

\section{Primer registro de una hembra de tortuga carey, Eretmochelys imbricata, en el Mosaico de Conservación Bahía Málaga, Pacífico colombiano}

\author{
First report of a female hawksbill turtle, Eretmochelys imbricata, in \\ the Conservation Mosaic Bahía Málaga, Colombian Pacific
}

\author{
Karla G. Barrientos-Muñoz ${ }^{1,2,3^{*}}$, Miller Valencia Díaz ${ }^{4,5}$, Carlos Andrés Hinojosa Romero ${ }^{6}$, Santiago Valencia-González ${ }^{4,5}$ \\ $\begin{array}{llll}\text { (D) } 0000-0003-3963-5727 & \text { (D) } 0000-0003-3877-1006 & \text { (D) } 0000-0001-9260-4263 & \text { (D) } 0000-0002-0549-8958\end{array}$ \\ María Claudia Diazgranados ${ }^{7}$, Edward Leonardo Sevilla Dueñas ${ }^{8}$ y Cristian Ramírez-Gallego ${ }^{1,2}$ \\ $\begin{array}{lll}\text { (D) } 0000-0001-8237-9840 & \text { (iD } 0000-0002-8319-7333 & \text { (iD) } 0000-0001-9485-5736\end{array}$ \\ 1.Fundación Tortugas del Mar (FTM),Envigado,Colombia.karla.barrientos@udea.edu.co*,cristian.ramirez@udea.edu.co \\ 2. Iniciativa Carey del Pacifico Oriental (ICAPO). \\ 3. Wider Caribbean Sea Turtle Conservation Network (Widecast), Colombia. \\ 4. Consejo Comunitario de las Comunidades Negras de La Plata-Bahía Málaga, Colombia.santiagov1986@hotmail.com; consejobahiamalaga@gmail.com \\ 5. Asociación Comunitaria de Bahía Málaga (Ecomanglar), Buenaventura, Colombia. ecomanglarpacifico@gmail.com \\ 6. Asociación de Pescadores Tradicionales de Bahía Málaga Los Esteros, Buenaventura, Colombia. carlosa1989@hotmail.es \\ 7. Conservación Internacional, Colombia.mdiazgranados@conservation.org \\ 8. Corporación Autónoma Regional del Valle del Cauca (CVC), Buenaventura, Colombia. biologosevilla@gmail.com \\ * Autora de correspondencia.
}

\section{RESUMEN}

$\mathrm{L}$ a tortuga carey del Pacífico oriental es una de las unidades regionales de manejo más amenazadas del mundo. En el Pacífico colombiano ha sido avistada en áreas de alimentación y en estadios juveniles y/o subadultos. Sus zonas y temporada de anidación son desconocidas para el país. El 24 de febrero de 2020, se registra la primera hembra de tortuga carey para el Pacífico colombiano, en el Mosaico de Conservación Bahía Málaga. El largo curvo mínimo del caparazón fue de $90 \mathrm{~cm}$, el largo curvo del caparazón nucalsupracuadal fue de $90,5 \mathrm{~cm}$, el ancho curvo del caparazón fue de 73,6 cm y su peso fue de $69 \mathrm{~kg}$. La presencia de una hembra y ser la principal zona de alimentación y residencia de juveniles y subadultos de la especie en el Pacífico de Colombia hace indispensable continuar con el monitoreo sistemático en agua e identificar y monitorear potenciales sitios de anidación para aportar a la conservación de la tortuga carey del Pacífico oriental.

PALABRAS CLAVE: tortuga carey, En Peligro Crítico, Pacífico colombiano, Pacífico oriental

\section{ABSTRACT}

$\mathrm{T}$ The Eastern Pacific hawksbill turtle is one of the most threatened management units in the world. In the Colombian Pacific it has been detected in feeding areas and in juvenile and / or sub adult's stages. Its nesting areas and season are unknown to the country. On February 24 $4^{\text {th }}, 2020$, the first female hawksbill turtle for the Colombian Pacific was reported, in the Conservation Mosaic of Bahía Málaga. The minimum curved carapace length was $90 \mathrm{~cm}$, the curved carapace length nuchal-tip was $90.5 \mathrm{~cm}$, the curved carapace width was $73.6 \mathrm{~cm}$ and its weight was $69 \mathrm{~kg}$. The presence of a female and being the main feeding and residence area for juvenile and sub adult of the species in the Pacific of Colombia makes it essential to continue systematic monitoring in-water and identify and monitor potential nesting sites to contribute to the conservation of the hawksbill turtle at Eastern Pacific.

KEYWORDS: hawksbill turtle, Critically Endangered, Colombian Pacific, Eastern Pacific 
La tortuga carey (Eretmochelys imbricata) es considerada la especie de tortuga marina con mayor sobreexplotación antropogénica, con una disminución $>80 \%$ de su población mundial (Meylan y Donelly, 1999; Mortimer y Donnelly, 2008; Barrientos et al., 2015; Ramírez-Gallego y Barrientos-Muñoz, 2020). Se encuentra categorizada En Peligro Crítico (CR) de extinción en la lista roja de la Unión Internacional para la Conservación de la Naturaleza (UICN) (Mortimer y Donnelly, 2008) y bajo la misma categoría a nivel nacional en el Libro rojo de reptiles de Colombia (Barrientos et al., 2015). Además, listada en la Convención sobre el Comercio Internacional de Especies Amenazadas de Fauna y Flora Silvestres (CITES) (Rhodin et al., 2018), la Convención sobre la Conservación de las Especies Migratorias de Animales Silvestres (CMS) y el Protocolo Relativo a las Áreas y Flora y Fauna Silvestres Especialmente Protegidas (SPAW) (Barrientos et al., 2015).

La tortuga carey en el Océano Pacífico Oriental (OPO) es una de las unidades regionales de manejo (URM) más amenazadas en el mundo (Wallace et al., 2011). Era considerada casi ausente en la región (Mortimer y Donnelly, 2008), y Colombia no era la excepción (Gaos et al., 2010; Trujillo-Arias et al., 2014). Desde 2007 se empiezan a registrar playas de anidación y zonas de alimentación a lo largo del OPO (Alfaro-Shiqueto et al., 2010; Gaos et al., 2010, 2012, 2017; Liles et al., 2011; Quiñones et al., 2011; Brittain et al., 2012; Carrión-Cortez et al., 2013; Chacón-Chaverri et al., 2014; Heidemeyer et al., 2014; Tobón-López y Amorocho, 2014; Barrientos et al., 2015). Se estiman menos de 700 hembras anidantes entre México y Perú (Gaos et al., 2017).

En el Pacífico colombiano, se desconoce su época y áreas de anidación, siendo avistada exclusivamente en áreas de alimentación y en estadios juveniles y/o subadultos (Gaos et al., 2010, Tobón-López y Amorocho, 2014; Barrientos-Muñoz et al., 2015). En 2006 durante la caracterización de las formaciones coralinas en la ensenada del Parque Nacional Natural (PNN) Utría se evidenciaron juveniles alrededor de los parches del Coral de la Aguada, Punta Diego y Playa Blanca (RamírezGallego, com. pers.), y ocasionalmente son capturados en redes de pesca por la comunidad local del corregimiento de El Valle, Bahía Solano (Barrientos-Muñoz y RamírezGallego, datos inéditos). En el Santuario de Flora y Fauna (SFF) Malpelo hay avistamiento esporádico de juveniles, mientras se realiza el monitoreo de los tiburones, al
The hawksbill turtle (Eretmochelys imbricata) is considered the species of sea turtle with the greatest anthropogenic overexploitation, with a $>80 \%$ decrease in its world population (Meylan and Donelly, 1999; Mortimer and Donnelly, 2008; Barrientos et al., 2015; RamírezGallego and Barrientos-Muñoz, 2020). The hawksbill turtle is classified as Critically Endangered (CR) on the Red List of the International Union for Conservation of Nature (IUCN) (Mortimer and Donnelly, 2008) and under the same category at the national level in the Red Book of Reptiles of Colombia (Barrientos et al., 2015). In addition, listed in the Convention on International Trade in Endangered Species of Wild Fauna and Flora (CITES) (Rhodin et al., 2018), the Convention on the Conservation of Migratory Species of Wild Animals (CMS), and the Protocol Relating to Areas and Specially Protected Wild Fauna Flora (SPAW) (Barrientos et al., 2015).

The hawksbill turtle in the Eastern Pacific Ocean (EPO) is one of the most threatened regional management units (RMUs) worldwide (Wallace et al., 2011). It was considered almost absent in the region (Mortimer and Donelly, 2008), and Colombia was no exception (Gaos et al., 2010; Trujillo-Arias et al., 2014). Since 2007, nesting beaches and feeding areas have been reported throughout the EPO (Alfaro-Shiqueto et al., 2010; Gaos et al., 2010, 2012, 2017; Liles et al., 2011; Quiñones et al., 2011; Brittain et al., 2012; Carrión-Cortez et al., 2013; ChacónChaverri et al., 2014; Heidemeyer et al., 2014; TobónLópez and Amorocho, 2014; Barrientos et al., 2015). Less than 700 nesting females are estimated between Mexico and Peru (Gaos et al., 2017).

In the Colombian Pacific, its season and nesting areas are unknown, being sighted exclusively in feeding areas and in juvenile and/or subdult stages (Gaos et al., 2010, Tobón-López and Amorocho, 2014; BarrientosMuñoz et al., 2015). In 2006, during the characterization of the coral formations in the Utria National Natural Park (NNP) cove, juveniles were evident around the Coral de la Aguada, Punta Diego and Playa Blanca patches (RamírezGallego, unpublished data) and occasionally they were caught in fishing nets by the local community of the township of El Valle, Bahía Solano (Barrientos-Muñoz and Ramírez-Gallego, pers. comm.). In the Malpelo Flora and Fauna Sanctuary (FFS), there is sporadic sighting of juveniles, while monitoring sharks, as well as for the Gulf of Tribugá (Fundación Malpelo, pers. comm.). In the Gorgona NNP, 41 individuals were reported between 1982- 
igual que para el golfo de Tribugá (Fundación Malpelo, com. pers). En el PNN Gorgona, 41 individuos fueron registrados entre 1982-2007 (Gaos et al., 2010; TobónLópez y Amorocho, 2014). Entre 2008-2019, 84 individuos fueron capturados y 38 de estos recapturados. El $100 \%$ son individuos juveniles, asociados a los arrecifes de coral de la isla donde se encuentra una pequeña población residente (Payán y Zorrilla, com. pers).

El Mosaico de Conservación Bahía Málaga incluye el PNN Uramba-Bahía Málaga, el Parque Regional Natural (PNR) de La Sierpe, el Distrito de Manejo Integrado (DMI) La Plata, bahía Málaga, territorios colectivos de comunidades negras y resguardos indígenas. El mosaico proporciona una gran cantidad de hábitats siendo uno de los lugares de mayor biodiversidad en el mundo. Desde el 2016, monitoreos participativos e interinstitucionales terrestres y acuáticos, han sido llevados a cabo para identificar potenciales áreas de anidación y de alimentación. Igualmente se han desarrollado encuestas y proyectos de educación ambiental para contribuir a los esfuerzos actuales en el mosaico, enfocados en la recuperación de la especie en el ámbito local y regional y en la reducción de sus amenazas locales.

El 24 de febrero de 2020, bajo el proyecto de "Valoración biológica, ecológica y cultural en el territorio marino-costero del área de influencia del Consejo Comunitario de La Plata" en el PNR La Sierpe y el DMI La Plata, se registra la primera hembra de tortuga carey para el Pacífico colombiano. La hembra fue capturada $\left(4,04485^{\circ} \mathrm{N}-77,26756^{\circ} \mathrm{O}\right)$ usando una red de enmalle elaborada en multifilamento de nylon torsionado (calibre 18), de $100 \mathrm{~m}$ de longitud por $8 \mathrm{~m}$ de fondo y luz de malla de $50 \mathrm{~cm}$, durante el monitoreo acuático estandarizado para el área. Posteriormente fueron registrados sus datos biométricos, se realizó marcaje, revisión general y liberación con miembros de la comunidad.

El largo curvo mínimo del caparazón (LCCmin) fue de $90 \mathrm{~cm}$, el largo curvo del caparazón nucal-supracuadal (LCCn-s) fue de 90,5 cm y el ancho curvo del caparazón (ACC) fue de $73,6 \mathrm{~cm}$, medidos con una cinta métrica $( \pm 0,1 \mathrm{~cm})$. El peso fue de $69 \mathrm{~kg}$, registrado con balanza mecánica $(0,01 \mathrm{~kg})$. Dos marcas metálicas tipo Inconel 681C (National Band \& Tag, Newport, KY, EE. UU.) fueron puestas en sus aletas delanteras con numeración ME761 (derecha) y ME762 (izquierda), así como una etiqueta interna Transmisor Pasivo Integrado (PIT por sus siglas en inglés) tipo DNAchip ISO (AVID Identification
2007 (Gaos et al., 2010; Tobón-López and Amorocho, 2014). Between 2008-2019, 84 individuals were captured and 38 of these were recaptured. The $100 \%$ are juvenile individuals, associated with the island's coral reefs where a small resident population is found (Payán and Zorrilla, pers. comm.).

The Conservation Mosaic Bahía Málaga includes the Uramba NNP-Bahía Málaga, the La Sierpe Natural Regional Park (NRP), the La Plata Integrated Management District (IMD), bahía Málaga, collective territories of AfroColombian communities and indigenous reservations. The mosaic provides a large number of habitats, being one of the most biodiverse places in the world. Since 2016, participatory and inter-institutional terrestrial and aquatic monitoring has been carried out to identify potential nesting and feeding areas. Likewise, surveys and environmental education projects have been developed to contribute to the current efforts in the mosaic focused on the recovery of the species at the local and regional level and the reduction of its local threats.

On February 24th, 2020, under the "Biological, Ecological and Cultural Assessment project in the coastal marine territory of the area of influence of the La Plata Community Council" in La Sierpe NRP and La Plata IMD, the first female hawksbill turtle was reported for the Colombian Pacific. The female was captured $\left(4.04485^{\circ} \mathrm{N}\right.$ $77.26756{ }^{\circ} \mathrm{W}$ ) using a gill net made of twisted nylon multifilament (18 gauge), $100 \mathrm{~m}$ long by $8 \mathrm{~m}$ deep and $50 \mathrm{~cm}$ mesh size, during standardized aquatic monitoring for the area. Biometric data, tagging, and general examination were recorded and subsequently the hawksbill turtle was released with members of the community.

The minimum curved carapace length (CCLmin) was $90 \mathrm{~cm}$, the curved carapace length nuchal-tip (CCLn-t) was $90.5 \mathrm{~cm}$ and the curved carapace width $(\mathrm{CCW})$ was $73.6 \mathrm{~cm}$, taken with a tape measure $( \pm 0.1 \mathrm{~cm})$. The weight was $69 \mathrm{~kg}$, recorded with a mechanical weight scale $(0.01 \mathrm{~kg})$. Two Inconel metal tag 681C type (National Band \& Tag, Newport, KY) were applied to its front flipper with numbering ME761 (right) and ME762 (left), as well as an internal Passive Integrated Transponder (PIT) tag type DNAchip ISO (AVID Identification Systems, Inc, Norco, CA) on its right front flipper numbered 977200008546271. The external physical condition of the female was checked and 20 barnacles, Chelonibia testudinaria, were removed: 13 from the shell, three from the head and four from the plastron. 
Systems, Inc, Norco, CA, EE. UU.) en su aleta delantera derecha con numeración 977200008546271 . La condición física externa de la hembra fue revisada y fueron retirados 20 balanos Chelonibia testudinaria: 13 del caparazón, tres de la cabeza y cuatro del plastrón.

La fecha del hallazgo de la hembra concuerda con el pico de anidación (enero y febrero) para la especie en Suramérica (Gaos et al., 2017). El LCCn-s 90,5 cm está por encima del promedio $(84,6 \pm 7,3 \mathrm{~cm} ; \mathrm{n}=691)$ registrado para la región (El Salvador, Nicaragua y Ecuador) (Gaos et al., 2017). Por otra parte, las hembras de la tortuga carey en Suramérica parecen evidenciar un mayor tamaño promedio. El tamaño de la hembra es muy cercano a lo registrado para Machalilla, Ecuador (LCCn-s: $91,2 \pm 6,9 \mathrm{~cm} ; \mathrm{n}=158$ ), coincidiendo con la colonia anidante más cercana identificada.

Además de la presencia de juveniles de la tortuga carey en el Mosaico de Conservación Bahía Málaga y ser el área más importante para la especie en el Pacífico colombiano, es prioritario continuar con el monitoreo sistemático en agua e identificar y monitorear potenciales sitios de anidación, para aportar a la conservación de la especie en la región y ayudar a llenar vacíos de información para la tortuga carey en el Pacífico oriental.

\section{AGRADECIMIENTOS}

El proyecto fue posible gracias al trabajo en campo de los investigadores locales Edgar López, Vanessa Moreno, Otoniel Angulo, Vicente González, Yoselín Sinisterra, Maicol Valencia, Isabelino Valencia, Eddie Rebolledo, Jeiler Caicedo y Rubén Canga. Un especial agradecimiento a las comunidades de La Plata, Miramar, Mangaña y La Sierpe y a sus pescadores, quienes han participado activamente del proyecto. A la Corporación Autónoma Regional del Valle del Cauca (CVC), en la Dirección Ambiental Regional Pacífico Oeste en Buenaventura, por su apoyo logístico. A Jeffrey Seminoff del National Marine Fisheries Service (NOAA), bajo el Marine Turtle Research Program, que provee las marcas metálicas en el marco del Pacific Sea Turtle Flipper Tagging Program. El proyecto fue financiado en el marco de La Minga, el esquema de sostenibilidad financiera de las áreas protegidas regionales del Pacífico colombiano, liderado por Fondo Acción y Conservación Internacional Colombia, la Corporación del Valle del Cauca (CVC), los consejos comunitarios de La Plata-Bahía Málaga y Chucheros, con fondos y capital
The date of the female finding is consistent with the nesting peak (January and February) for the species in South America (Gaos et al., 2017). The CCLn-t $90.5 \mathrm{~cm}$ is above the average $(84.6 \pm 7.3 \mathrm{~cm} ; \mathrm{n}=691)$ reported for the region (El Salvador, Nicaragua and Ecuador) (Gaos et al., 2017). On the other hand, female hawksbill turtles in South America seem to show a larger average size. The size of the female is very close to that reported for Machalilla, Ecuador (CCLn-t: $91.2 \pm 6.9 \mathrm{~cm} ; \mathrm{n}=158$ ), coinciding with the closest nesting colony identified.

In addition, due to the presence of juvenile hawksbill turtles in the Conservation Mosaic Bahía Málaga and being the most important area for the species in the Colombian Pacific, it is a priority to continue systematic monitoring in-water and identify and monitor potential nesting sites, to contribute to the conservation of the species in the region and help fill information gaps for the hawksbill turtle in the Eastern Pacific.

\section{ACKNOWLEDGMENTS}

The project was possible thanks to the field work of local volunteers: Edgar López, Vanessa Moreno, Otoniel Angulo, Vicente González, Yoselín Sinisterra, Maicol Valencia, Isabelino Valencia, Eddie Rebolledo, Jeiler Caicedo, and Rubén Canga. A special thanks to the communities of La Plata, Miramar, Mangaña and La Sierpe and their fishermen, who have actively participated in the project. To the Corporación Autónoma Regional del Valle del Cauca (CVC), in the West Pacific Regional Environmental Directorate in Buenaventura, for their logistical support. To Jeffrey Seminoff of National Marine Fisheries Service (NOAA) under the Marine Turtle Research Program who provides the metal marks under the Pacific Sea Turtle Flipper Tagging Program. The project was financed within the framework of La Minga, the financial sustainability scheme of the regional protected areas of the Colombian Pacific, led by Fondo Acción and Conservación Internacional Colombia, la Corporación del Valle del Cauca (CVC), La Plata-Bahía Málaga and Chucheros Community Councils, and with funds and human capital from Fundación Tortugas del Mar, the Association of Traditional Fishermen of Bahía Málaga Los Esteros, La Plata-Bahía Málaga Black Communities Community Council and the Community Association of Bahía Málaga (Ecomanglar). 
humano de la Fundación Tortugas del Mar, la Asociación de Pescadores Tradicionales de Bahía Málaga Los Esteros, el Consejo Comunitario de las Comunidades Negras de La Plata-Bahía Málaga y la Asociación Comunitaria de Bahía Málaga (Ecomanglar).

\section{BIBLIOGRAFÍA/LITERATURE CITED}

Alfaro-Shiqueto, J., J.C. Mangel, C. Cáceres, J.A. Seminoff, A.R. Gaos, and I. Yáñez. 2010. Hawksbill turtles in Peruvian coastal fisheries. Mar. Turtle Newslett., 129: 19-21.

Barrientos-Muñoz, K., C. Ramírez-Gallego y V.P. Páez. 2015. Eretmochelys imbricata (Linnaeus, 1766). 127-131. En: Morales-Betancourt, M.A., C.A. Lasso, V.P. Páez y B.C. Bock (Eds.). Libro rojo de reptiles de Colombia. 2015. Inst. Invest. Rec. Biol. Alexander von Humboldt (IAvH), Universidad de Antioquia. Bogotá, D.C. 258 p.

Brittain, R., S. Handy, and S. Lucas. 2012. Two reports of juvenile Hawksbill sea turtles (Eretmochelys imbricata) on the southeast coast of Guatemala. Mar. Turtle Newslett., 133: 20-22.

Carrión-Cortez, J., C. Canales-Cerro, R. Arauz, and R. Riosmena-Rodríguez. 2013. Habitat use and diet of juvenile Eastern Pacific hawksbill turtles (Eretmochelys imbricata) in the North Pacific coast of Costa Rica. Chelonian Conserv. Biol., 12(2): 235-245.

Chacón-Chaverri, D., D.A. Martínez-Cascante, D. Rojas y L.G. Fonseca. 2014. Golfo Dulce, Costa Rica, un área importante de alimentación para la tortuga carey del Pacífico Oriental (Eretmochelys imbricata). Rev. Biol. Trop., 63: 351-362.

Gaos, A.R., F.A. Abreu-Grobois, J. Alfaro-Shigueto, D. Amorocho, R. Arauz, A. Baquero, R. Briseno, D. Chacón, C. Dueñas, C. Hasbún, M. Liles, G. Mariona, C. Muccio, J.P. Munoz, W.J. Nichols, M. Peña, J.A. Seminoff, M. Vásquez, J. Urteaga, B. Wallace, I.L. Yáñez, and P. Zárate. 2010. Signs of hope in the Eastern Pacific: international collaboration reveals encouraging status for a severely depleted population of hawksbill turtles Eretmochelys imbricata. Oryx, 44(4): 595-601.

Gaos, A.R., M. Liles, V. Gadea, A. Peña de Niz, F. Vallejo, M. Cristina, J. Darquea, A. Henríquez, A. Rivera, S. Chavarría, D. Melero, J. Urteaga, C. Pacheco, D. Chacón, C. LeMarie, J. Alfaro-Sigueto, J. Mangle, I. Yáñez, and J. Seminoff. 2017. Living on the edge: hawksbill turtle nesting and conservation along the Eastern Pacific rim. Lat. Am. J. Aquat. Res., 45(3): 572-584.

Gaos, A.R., R.L. Lewison, B.P. Wallace, I.L. Yáñez, M.J. Liles, W.J. Nichols, A. Baquero, C.R. Hasbún, M. Vásquez, J. Urteaga, and J.A. Seminoff. 2012. Spatial ecology of Critically Endangered hawksbill turtles Eretmochelys imbricata: implications for management and conservation. Mar. Ecol. Prog. Ser., 450: 181-198.

Heidemeyer, M., R. Arauz-Vargas, and E. López-Agüero. 2014. New foraging grounds for hawksbill (Eretmochelys imbricata) and green turtles (Chelonia mydas) along the northern Pacific coast of Costa Rica, Central America. Rev. Biol. Trop., 62: 109-118.

Liles, M.J., M.V. Jandres, W.A. López, G.I. Mariona, C.R. Hasbún, and J.A. Seminoff. 2011. Hawksbill turtles Eretmochelys imbricata in El Salvador: nesting distribution and mortality at the largest remaining nesting aggregation in the Eastern Pacific Ocean. Endang. Species Res., 14: 23-30.

Meylan, A.B. and M. Donelly. 1999. Status justification for listing the hawksbill turtle (Eretmochelys imbricata) as Critically Endangered on the 1996 IUCN Red List of Threatened Animals. Chelonian Conserv. Biol., 3(2): 200-224.

Mortimer, J.A. and M. Donnelly (IUCN SSC Marine Turtle Specialist Group). 2008. Eretmochelys imbricata. The IUCN Red List of Threatened Species 2008. Version 2014.3.1 www.iucnredlist.org. 06/12/2020.

Quiñones, J., J. Zeballos, S. Quispe, and L. Delgado. 2011. Southernmost records of hawksbill turtles along the east Pacific coast of South America. Mar. Turtle Newslett., 130: 16-21

Ramírez-Gallego, C. and K.G. Barrientos-Muñoz. 2020. Illegal hawksbill trafficking: five years of records of the handicrafts and meat trades of the hawksbill turtle (Eretmochelys imbricata) in Cartagena de Indias, Colombia. J. Aquacult. Mar. Biol., 9(3): 101-105. https://doi.org/10.3389/ fmars.2019.00817

Rhodin, A.G., C.B. Stanford, P.P. Van Dijk, C. Eisemberg, L. Luiselli, R.A. Mittermeier, et al. 2018. Global conservation status of turtles and tortoises (order Testudines). Chel. Cons. Biol., 17(2): 135-161. https://doi.org/10.2744/CCB-1348.1 
Tobón-López, A. and D.F. Amorocho. 2014. Population study of the hawksbill turtle Eretmochelys imbricata (Cheloniidae) in the southern Pacific region of Colombia. Acta Biol. Colomb., 19(3): 447-457.

Trujillo-Arias, N., D.F. Amorocho, D. López-Álvarez, and L.M Mejía-Ladino. 2014. Phylogeographic relations of some feeding and nesting of hawksbill turtle rookeries (Eretmochelys imbricata) in the Caribbean and Pacific of Colombia. Bol. Invest. Mar. Cost., 43(1): 159-182.

Wallace, B.P., A.D. DiMatteo, A.B. Bolten, M.Y. Chaloupka, B.J. Hutchinson, F.A. Abreu-Grobois, et al. 2011. Global conservation priorities for marine turtles. PLoS ONE, 6(9): e24510.

RECIBIDO/RECEIVED: 28/07/2020

ACEPTADO/ACCEPTED: $18 / 11 / 2020$ 